\title{
Studi Komparasi Pemanfaatan Bahan Pemantap Tanah Jenis Lateks dan Polyacrilamide (Pam) dalam Campuran Hydroseeding terhadap Pertumbuhan Vegetasi Jenis Rumput dan Cover Crop
}

\author{
Sri Yeni Mulyani \\ Pusat Litbang Jalan dan Jembatan
}

\begin{abstract}
Hydroseeding is an alternative to traditional seed-sowing vegetative technology by mixing other ingredients such as tackifiers (soil amendment), fertilizers, mulch, water, or other materials sprayed using hydraulic pumps (Siswomartono, 1989). In general, the soil amendment used in the hydroseeding mixture is a type of polyacrilamide (PAM). The use of PAM in hydroseeding mixtures still has a deficiency of less stable soil aggregate bonds after being sprayed (dry) on the slope surface (Sunandar, 201). The soil aggregate bond is one of the factors that affect the soil resistance to erosion caused by rain water. Therefore, to answer these problems need to look for other adhesive materials that can bind aggregate soil to be better or stable. Latex is an alternative answer to the problem, however, the effect of latex on the growth of vegetation seeds in the hydroseeding mixture has not been studied. The purpose of this research paper is to compare the utilization of latex and polyacrilamide (PAM) in the mixture of hydroseeding to the growth of grass and cover crop vegetation. The research method used is RAK in time with 9 treatments, namely: PAM + grass seeds, latex + grass seeds bermuda, PAM + cover crop PJ, latex + cover crop seeds PJ, PAM + grass seeds rhodes, latex + grass seeds rhodes, PAM + grass seeds signal, latex + grass seeds signal and grass vetiver with 3 repetitions. The results showed an interaction between the combination of seeds and the soil amendment with time. In addition, this study shows that the use of Latex and PAM has no significant effect on growth. Therefore, hydroseeding technology using latex type feeding material is good enough to replace PAM
\end{abstract}

Key Words: Hydroseeding, Lateks, Polyacrylamid (PAM), Rhodes, Signal, Bermuda, PJ

\begin{abstract}
Abstrak. Hydroseeding merupakan alternatif teknologi vegetatif penaburan benih secara tradisional dengan mencampurkan bahan lainnya seperti tackifier (bahan pemantap), pupuk, mulsa, air, atau bahan lainnya yang disemprotkan menggunakan pompa hidrolik (Siswomartono, 1989). Pada umumnya, bahan pemantap tanah yang digunakan dalam campuran hydroseeding adalah jenis bahan pemantap polyacrilamide (PAM). Penggunaan PAM dalam campuran hydroseeding masih memiliki kekurangan yaitu ikatan antar agregat tanah kurang stabil setelah disemprotkan (kering) pada permukaan lereng (Sunandar, 2015). Ikatan agregat tanah merupakan salah satu faktor yang berpengaruh terhadap ketahanan tanah terhadap erosi yang disebabkan oleh air hujan. Oleh karena itu, untuk menjawab permasalahan tersebut perlu dicari bahan perekat lain yang mampu mengikat agregat tanah menjadi lebih baik atau stabil. Lateks merupakan salah satu alternatif jawaban permasalahan tersebut, namun demikian pengaruh lateks terhadap pertumbuhan biji vegetasi dalam campuran hydroseeding tersebut belum dikaji. Tujuan penulisan makalah penelitian ini adalah membandingkan pemanfaatan bahan pemantap tanah jenis lateks dan polyacrilamide (PAM) dalam campuran hydroseeding terhadap pertumbuhan vegetasi jenis rumput dan cover crop. Metode penelitian yang digunakan adalah RAK in time dengan 9 perlakuan yaitu: PAM + biji rumput bermuda, lateks + biji rumput bermuda, PAM + cover crop PJ, lateks + cover crop PJ, PAM + biji rumput rhodes, lateks + biji rumput rhodes, PAM + biji rumput signal, lateks + biji rumput signal dan rumput vetiver dengan 3 kali pengulangan. Hasil penelitian menunjukkan adanya interaksi antara kombinasi biji dan bahan pemantap dengan waktu. Selain itu penelitian ini menunjukkan bahwa penggunaan Lateks dan PAM tidak memiliki pengaruh yang signifikan terhadap pertumbuhan. Untuk itu teknologi hydroseeding dengan menggunakan bahan pemantap jenis lateks cukup baik untuk menggantikan PAM
\end{abstract}

Kata Kunci: Hydroseeding, Lateks, Polyacrylamid (PAM), Rhodes, Signal, Bermuda, PJ

\section{A. PENDAHULUAN}

Vegetasi merupakan lapisan
pelindung atau penyangga antara

atmosfer dan tanah. Suatu vegetasi penutup tanah yang baik seperti rumput yang tebal atau rimba yang 
lebat akan menghilangkan pengaruh hujan dan topografi terhadap erosi (Arsyad, 2010). Vegetasi mempengaruhi siklus hidrologi melalui pengaruhnya terhadap air hujan yang jatuh dari atmosfer ke permukaan bumi, ke tanah, dan batuan di bawahnya. Oleh karena itu, vegetasi mempengaruhi volume air yang masuk ke sungai dan danau, ke dalam tanah dan cadangan air di bawah tanah. Bagian vegetasi yang ada di atas permukaan tanah, seperti daun dan batang menyerap energi perusak hujan, sehingga mengurangi dampak terhadap tanah. Bagian vegetasi yang ada di dalam tanah yang terdiri atas sistem perakaran, meningkatkan kekuatan mekanik tanah (Styczen dan Morgan, 1995).

Pertumbuhan vegetasi dipengaruhi oleh dua faktor yaitu faktor dalam dan faktor luar (lingkungan). Faktor dalam atau faktor genetik adalah faktor vegetasi itu sendiri, yaitu sifat yang terdapat di dalam bahan tanam/benih yang digunakan dalam budidaya tanaman. Adapun yang dimaksud dengan bahan tanam/benih menurut Undang-undang RI No. 12 tahun 1992 tentang Sistem Budidaya Tanaman adalah tanaman atau bagiannya yang digunakan untuk memperbanyak dan/atau mengembangbiakkan tanaman. Faktor lingkungan (Arsyad, 2010) adalah faktor yang ada di sekeliling tanaman, di mana beberapa ilmuwan mengelompokkan faktor lingkungan ini menjadi dua kelompok, yaitu kelompok abiotik (iklim, tanah) dan kelompok biotik (makhluk hidup) yaitu biotik (tanaman dan hewan) dan anthrofis (manusia).

Penerapan teknologi hydroseeding dalam pertumbuhan vegetasi dapat dimasukkan dalam faktor lingkungan yaitu adanya peranan manusia dalam memperbaiki kondisi tanah (melalui pemberian mulsa, bahan pemantap tanah, pupuk dan air) sehingga mempengaruhi pertumbuhan vegetasi. Mulsa dalam campuran hydroseeding yang digunakan adalah mulsa organik yaitu mulsa serutan kayu. Penggunaan mulsa organik berfungsi menekan pertumbuhan gulma yang mengganggu tanaman utama, mempertahankan agregat tanah dari hantaman air hujan, memperkecil erosi permukaan tanah, mencegah penguapan air dan melindungi tanah dari terpaan sinar matahari. Selain itu, peranan mulsa dalam campuran hydroseeding dapat membantu memecah dormansi suatu benih dengan memberikan energi panas dari hasil dekomposisi yang akan memecah dormansi benih (Riyanto, dkk., 2010). Pemberian mulsa berupa serutan kayu berfungsi meningkatkan pertumbuhan tanaman muda dengan memberikan fasilitas perkembangan akar tanaman sehingga dapat secara nyata meningkatkan hasil tanaman (Mashayekhan dan Hojjati, 2013). Mulsa memiliki sifat menahan dan menyimpan air yang baik sehingga akan sangat dibutuhkan oleh tanaman selama proses pertumbuhan hal tersebut dapat berpengaruh terhadap bobot segar tanaman yang akan dihasilkan. Berdasarkan hasil penelitian Yulinda (2009) menunjukkan bahwa pemberian serbuk gergaji sebagai mulsa organik dapat berpengaruh pada peningkatan tinggi tanaman. Pemberian bahan pemantap tanah dalam campuran hydroseeding dapat meningkatkan berat segar dan berat kering tanaman. Hal ini terbukti dari hasil penelitian Masduqi, dkk. (2012) di mana berat segar dan berat kering tanaman kacang hijau meningkat setelah diberi bahan pemantap tanah yang kemudian dapat 
meningkatkan kapasitas lapang atau kemampuan tanah dalam menahan air. Pengaruh kombinasi antara mulsa yang berperan sebagai bahan organik dan bahan pemantap tanah sebagai perekat, mampu memberikan ketersediaan unsur hara yang dibutuhkan oleh tanaman dan perbaikan pada tanah selama proses pertumbuhan tanaman menjadi dewasa. Bahan pemantap tanah yang digunakan dalam campuran hydroseeding adalah jenis bahan pemantap polyacrilamide (PAM). PAM adalah polymer non-hidrophobik yang mempunyai bagian aktif amide yang mengikat bagian-bagian - $\mathrm{OH}$ pada butir liat melalui ikatan hidrogen (Arsyad, 2010). Dalam kenyataannya, penggunaan PAM dalam campuran hydroseeding masih memiliki kekurangan yaitu daya rekatnya yang masih rendah (ikatan antar agregat tanahnya kurang stabil) setelah disemprotkan pada permukaan lereng (Sunandar, 2015). Oleh karena itu, untuk menjawab permasalahan tersebut perlu dicari bahan perekat lain yang memiliki daya rekat lebih baik dari PAM. Bahan perekat lain yang memungkinkan digunakan adalah Lateks dengan pertimbangan bahwa bahan tersebut berupa bahan lokal yang berlimpah dan harga murah. Menurut Sunandar dkk (2015), lateks setelah disemprotkan ke permukaan lereng (tanah) akan meresap ke dalam pori pori tanah (setebal $10 \mathrm{~cm}$ ) dan setelah mengering akan membentuk lapisan plastis yang mengikat agregat tanah menjadi lebih stabil. Namun demikian, pengaruh lateks terhadap pertumbuhan berbagai jenis vegetasi belum diteliti. Oleh karena itu dalam makalah ini akan dibahas pengaruh lateks dan PAM dalam campuran hydroseeding terhadap pertumbuhan tanaman rumput signal, rumput rhodes, rumput bermuda dan cover crop
(Plueria Javanica). Sebagai pembanding tingkat pertumbuhan vegetasi tersebut, maka ditanam juga rumput vetiver (non hydroseeding). Parameter pertumbuhan vegetasi yang diamati adalah tinggi dan penutupan.

\section{B. TINJAUAN PUSTAKA}

\section{Hydroseeding}

Hydroseeding adalah proses penanaman dengan menggunakan campuran yang terdiri dari biji tanaman, perekat, mulsa, pupuk dan air. Campuran tersebut kemudian diangkut dalam tangki truk atau trailer dan disemprotkan di atas lahan yang telah dipersiapkan dalam tapak yang seragam (Riyanto, dkk., 2014). Teknik hydroseeding sangat cocok di terapkan pada areal yang luas dan kondisi tanah dengan lereng yang terjal, hal ini jika dilakukan dengan penanaman secara tradisional akan sangat menyulitkan bahkan membahayakan jiwa seseorang.

\section{Mulsa Serutan Kayu}

Mulsa yang sering digunakan dalam campuran hydroseeding yaitu, mulsa jerami padi, sekam padi, limbah kertas, dan limbah serutan kayu. Serutan kayu merupakan salah satu limbah pertanian dari hasil industri kayu yang keberadaannya sangat melimpah di Indonesia yang dapat dijadikan sebagai mulsa organik. Dalam mulsa serutan kayu terdapat unsur - unsur kimia penyusun kayu yaitu, C (50\%), H (6\%), N (0,05 $0,10 \%)$, Abu $(0,20-0,50 \%)$ dan sisanya merupakan oksigen (Dumanauw, 2001). Mulsa serutan kayu merupakan jenis mulsa yang memiliki ketahanan terhadap daya tumbuk air hujan dan lama mengalami proses dekomposisi sehingga dapat berperan dalam memperkecil erosi tanah selama proses perkecambahan tanaman sampai dewasa. Mulsa yang 
terkandung dalam campuran hydroseeding dapat membantu dalam menjaga kelembaban benih (Kusminingrum dan Sunandar, 2014). Bahan organik yang memiliki kandungan $\mathrm{C} / \mathrm{N}$ rasio $10-20 \%$ mampu melepaskan unsur hara yang terikat pada humus melalui proses mineralisasi sehingga dapat dibutuhkan oleh tanaman. Dengan penambahan bahan organik yang memiliki $\mathrm{C} / \mathrm{N}$ rasio yang tinggi pada tanaman, maka akan terjadi persaingan memperebutkan unsur hara dengan mikroorganisme yang akan merombak bahan organik tersebut (Novizan, 2002). Mikroorganisme akan mati jika $\mathrm{C} / \mathrm{N}$ rasio rendah sehingga terjadi inmeralisasi $\mathrm{N}$ menjadi senyawa yang sederhana (Sutanto, 2005). Penggunaan mulsa pada hydroseeding yang disemprotkan mampu menekan laju erosi hingga 62\% dibandingkan dengan pemulsaan biasa yang ditaburkan di atas tanah. Hal ini karena mulsa yang disemprotkan pada tanah mempunyai daya hantar sehingga menempel dengan kuat pada tanah dan mulsa tersebut dapat menjadi bahan organik yang dibutuhkan oleh tanaman. Mulsa organik juga dapat mengurangi laju aliran permukaan karena sifatnya sebagai bahan organik sehingga memacu pertumbuhan akar tanaman yang membuat pori tanah menjadi baik (Morris, 2007)

\section{Bahan Pemantap Tanah Polyacrylamide (PAM) dan Lateks}

Berdasarkan peraturan menteri pertanian nomor: 28 Tahun 2009, bahan pemantap tanah adalah bahanbahan sintetis atau alami, organik atau mineral yang berbentuk padat atau cair yang mampu memperbaiki sifat fisika, kimia dan biologi tanah. Menurut Sutono dan Abdurachman (1997) bahan pembenah tanah adalah bahan- bahan sintetis atau alami yang dapat memperbaiki sifat-sifat tanah dan mendukung pertumbuhan tanaman. Bahan pemantap tanah yang sering digunakan dalam campuran hydroseeding adalah PAM dan lateks. PAM adalah polymer non-hidrophobik yang mempunyai bagian aktif amide yang mengikat bagian-bagian - $\mathrm{OH}$ pada butir liat melalui ikatan hidrogen (Arsyad, 2010). Sedangkan lateks merupakan suatu larutan koloid dengan partikel karet dan bukan karet yang tersuspensi di dalam suatu media yang mengandung berbagai macam zat. Di dalam lateks mengandung 25-40\% bahan karet mentah (crude rubber) dan $60-75 \%$ serum yang terdiri dari air dan zat yang terlarut. Di Indonesia, lateks dalam bentuk polimer sudah banyak digunakan sebagai bahan stabilisasi tanah atau jalan namun demikian belum mampu memproduksi bahan tersebut (Moto dkk, 2004). Menurut Feldman (1995), lateks polimer merupakan suatu bahan untuk meningkatkan California bearing rasio (CBR).

Untuk bahan pemantap tanah jenis PAM, diperlukan $3 \mathrm{gram} / \mathrm{m} 2$, sedangkan untuk lateks $(48,75 \%)$ diperlukan 0,5 liter/m2. Penggunaan lateks sebagai bahan pemantap tanah perlu diperhatikan karena larutan lateks bersifat asam (pH 1 - 2). Oleh karena itu, perlu perlakuan tambahan, yaitu dengan menambahkan kapur dolomit sebanyak 25 gram $/ \mathrm{m} 2$ atau mencari Lateks yang memiliki pH normal (6-7). Adapun karakteristik fisik PAM dan lateks yang digunakan dalam capuran hydroseeding dapat dilihat pada Tabel 1 dan Tabel 2.

\section{Tabel 1}

Karakteristik Fisik Lateks

\begin{tabular}{lll}
\hline No & \multicolumn{1}{c}{ Karakteristik } & \multicolumn{1}{c}{ Hasil } \\
\hline 1. & Berat Jenis & 0,997 \\
\hline 2. & Solid Konten & $52,82 \%$ \\
\hline
\end{tabular}




\begin{tabular}{lll}
\hline No & Karakteristik & Hasil \\
\hline 3. & Kadar Karet & $48,75 \%$ \\
\hline 4. & Viskositas Brook Field & $750 \mathrm{cps}$ \\
\hline \multicolumn{2}{l}{ pH } & $1-2$ \\
\hline Sumber: Sunandar 2013 &
\end{tabular}

Tabel 2

Karakteristik Fisik PAM

\begin{tabular}{|c|c|c|}
\hline No & Karakteristik & Hasil \\
\hline 1 & Berat Jenis & 0,995 \\
\hline$\underline{2}$ & \multirow{2}{*}{\multicolumn{2}{|c|}{$\begin{array}{lc}\text { Viskositas } & \text { Brook50 gr, 45 detik } \\
\mathrm{pH} & 6-7\end{array}$}} \\
\hline 3 & & \\
\hline
\end{tabular}

Pada umumnya bahan pemantap tanah memiliki sifat pencegah erosi dengan memantapkan agregat tanah, mengubah sifat hidrophobik atau hidrophilik tanah dan mengurangi atau meningkatkan KTK tanah. Faktor yang mempengaruhi bahan pemantap tanah ini dalam perbaikan struktur tanah antara lain, berat molekul/polymer, kandungan air dalam tanah yang optimum dan konsentrasi emulsi. Pemberian bahan pemantap tanah memberikan pengaruh yang cukup baik dalam membantu perkecambahan benih, hal tersebut dapat terlihat ketika bahan pemantap tanah dicampur dengan air dan berubah menjadi gel. Gel tersebut yang memberikan perlindungan terhadap benih dari sinar matahari langsung dan dari pengaruh kekeringan (Riyanto, dkk, 2010).

\section{Vegetasi untuk bahan campuran Hydroseeding}

\section{Rumput Signal (Brachiaria decumbens)}

Rumput signal (Brachiaria decumbens) atau yang sering disebut juga rumput bede merupakan rumput pakan ternak jenis unggul di samping jenis rumput lainnya. Rumput signal berasal dari daerah Uganda, Afika.
Rumput signal termasuk jenis rumput yang berumur panjang dan tumbuh dengan hamparan yang lebat, selain itu dalam penyebarannya juga sangat cepat melalui stolon (Oyo, dkk., 1997). Rumput signal (Brachiaria decumbens) merupakan salah satu rumput yang baik ditanam untuk pengendalian erosi dan juga tahan terhadap kekeringan serta tetap hijau walaupun memasuki musim kemarau (Shelton, 2007).Rumput signal merupakan tanaman yang menjalar dengan stolon, tanaman ini berasal dari Afrika tropika dengan kemampuan menutup tanah yang baik pada daerah yang basah. Rumput signal termasuk dalam spesies rumput padang penggembalaan terbaik (Ilroy, 1977). Rumput dengan Tribus Paniceae ini menempati $51,6 \%$ penyebarannya di seluruh dunia, dengan komposisi 33,3 $\%$ di belahan bumi bagian barat dan $18,3 \%$ di belahan bumi bagian timur dan termasuk jenis Bachiaria decumbens diantaranya (Sumarsono, 2007).Rumput signal merupakan jenis rumput yang tahan terhadap daerah penggembalaan berat, karena tahan injakan, renggutan dan tahan kekeringan serta responsif terhadap pemupukan nitrogen. Rumput signal juga cepat dalam pertumbuhan dan berkembang, sehingga sangat cepat dalam menutup tanah dan berdampak baik dalam mengurangi erosi (Oyo, dkk., 1997).Rumput signal banyak dijumpai di pinggir jalan, pinggir selokan, pematang sawah, lapangan, tempat berbatu dan di tempat lainnya di daerah Indonesia. Perkembangan rumput signal di Indonesia sudah tersebar luas, namun perkembangan dalam budidaya atau secara ekonomi masih belum banyak dilakukan dibandingkan dengan jenis rumput lainnya seperti, rumput raja (king grass) dan rumput gajah (elephant 
grass) yang sudah dikenal luas oleh petani peternak (Oyo, dkk., 1997).

\section{Rumput Rhodes (Chlads Gayana)}

Rumput rhodes adalah salah satu runput sub tropis utama yang banyak ditanam di Afrika, Australia, Jepang, Amerika Serikat sebagai tanaman pertanian, sedangkan di Timur Tengah banyak digunakana baik untuk tujuan penghijauan maupun konservasi Tanah. Jenis rumput ini sering mendominasi ketika ditaburkan dalam campuran karena bibit akan tumbuh dan menyebar dengan cepat. Pada beberapa kasus, rumput rhodes hanya bertahan selama satu sampai dengan tiga tahun. Hal ini dapat disebabkan kesuburan yang rendah, Tanah basah, pembekuan, penggembalan yang melampaui batas dan persaingan dengan rumput tahunan. Rumput ini menjalar melalui stolon dan berumbai, tumbuh tegak dengan panjang batang antara $0,5-2$ $\mathrm{m}$, daun berbulu dengan panjang 15 $50 \mathrm{~cm}$ dan daun pada stolon lebih pendek, terdiri dari $2-4$ daun per nodes. Rumput dapat beradaptasi terhadap: i) curah hujan> $425 \mathrm{~mm}$. (ii) kekeringan seedang sampai dengan tinggi, (iii) pembekuan, (iv) tekstur Tanah medium sampai kasar, (v) $\mathrm{pH}>$ 4.3, (vi) Tanah yang mengandung aluminium sedang dan (vii) Tanah berkadar garam rendah sampai dengan agak sedang. Rumput rhodes berfungsi dalam pengendali erosi Tanah dan pengendali gulma. Rumput rhodes tumbuh secara aktif memasuki awal musim hujan sampai dengan musim gugur (awal Juni). Pada umumnya rumput ini akan dorman selama musim dingin dan akan tumbuh aktif pada awal musim semi dan tumbuh oportunis sepanjang musim panas. Hal ini bergantung pada ketersediaan air. Seperti kebanyakan rumput sub tropis lainnya, rumput rhodes lebih menyukai suhu tinggi dengan perkembangan maksimum pada $30^{\circ} \mathrm{C} / 25^{\circ} \mathrm{C}$ (suhu siang/malam). Pertumbuhan akan berkurang pada suhu di bawah $18^{\circ} \mathrm{C} / 13^{\circ} \mathrm{C}$.

http://archive.agric.wa.Gov.au/objtwr /imported0 assets/content/past/rhodes0gr ass.pdf

\section{Rumput Bermuda (Cynodon dactylon)}

Rumput bermuda paling banyak digunakan di Indonesia, dimana rumput ini awalnya dirancang untuk lapangan golf. Rumput Bermuda merupakan rumput perennial musim hangat yang tumbuh pada iklim subtropik dan juga tropik (Turgeon, 2002). Turgeon (2002) memaparkan bahwa rumput bermuda karakteristiknya keabu-abuan hijau, medium- untuk bertekstur kasar rumput yang mentorerir berat lalu lintas. Rumput bermuda memiliki kedalaman akar 1 / 4-inch, daun berbulu tajam dan bercabang serta penyebarannya cepat. Selain itu rumput Bermuda (Cynodon dactylon) merupakan jenis tanaman yang toleran pada kondisi salin (GOHL, 1981). Manfaat yang diperolah tanaman inang bila berasosiasi dengan CMA antara lain mampu meningkatkan penyerapan unsur hara dan air, meningkatkan ketahanan pada kondisi stress (kekeringan, pH rendah, salinitas tinggi, dan toksisitas logam berat (MARSCHNER,1995). Kelebihan rumput bermuda adalah tumbuh dan menyebar dengan cepat dan juga dapat bertahan dalam iklim panas, rumput bermuda yang ditanam di lahan miring sangat bermanfaat untuk melindungi tanah dari erosi (Sutrisno. 2011).

\section{Pueraria Javanica}

Pueraria javanica merupakan salah satu tanaman pakan yang dapat 
berfungsi sebagai tanaman penutup tanah di perkebunan. Genus Pueraria berasal dari Asia bagian Timur dan Kepulauan Pasifik. Legum ini bersifat membelit, merambat, dapat membentuk semak yang rimbun dengan perakaran yang berbentuk tuber yang kuat dengan pokok akar yang disebut mahkota (crown). Nama lain Pueraria javanica adalah Puero atau kacang ruji. Puero berbatang kuat dan berbulu, sedangkan varietas barunya mempunyai batang yang tidak berbulu (terdapat di Puerto Rico), mutan Puero ini lebih disukai ternak dibandingkan dengan Puero yang berbulu (Reksohadiprodjo, 1985). Puero mempunyai stolon yang dapat mengeluarkan akar dari tiap ruas batangnya yang bersinggungan dengan tanah. Perakarannya dalam dan bercabang-cabang, sehingga puero dapat berfungsi sebagai pencegah erosi, tahan musim kemarau yang tak terlalu panjang. Puero tahan terhadap tanah masam, tanah kekurangan kapur dan posfor. Puero digunakan sebagai makanan ternak, sangat palatable untuk ternak ruminansia (Allen dan Allen, 1981), tanaman penutup tanah, pencegah erosi dan pupuk hijau (Reksohadiprojo, 1985). Kandungan nutrisi Puero terdiri dari protein kasar 20,5\%; serat kasar 37,9\% dan lemak kasar 2,0\% (Gohl, 1981)

\section{HIPOTESIS}

Dari uraian latar belakang dan permasalahan yang terjadi di atas dapat diduga bahwa:

1. terdapat interaksi antara kombinasi biji vegetasi dengan bahan lateks dan PAM

2. terdapat perbedaan yang nyata antara penggunaan lateks dan PAM terhadap pertumbuhan tanaman

\section{METODOLOGI}

\section{Tempat dan Waktu Penelitian}

Penelitian ini dilaksanakan di Lereng Jalan Lingkar gentong Kabupaten Tasikmalaya dan Nagreg Kabupaten Garut dari bulan Januari 2015 sampai dengan Juli 2015.

\section{Bahan dan Alat Penelitian}

Bahan-bahan yang digunakan dalam penelitian ini adalah serutan kayu, PAM, lateks, biji rumput signal, biji rumput rhodes, biji rumput bermuda, Pueraria Javanica (PJ), pupuk kandang dan air.

Alat-alat yang digunakan dalam penelitian ini adalah meteran, ring behel dan alat bantu lainnya.

\section{Rancangan Percobaan}

Rancangan percobaan yang digunakan menggunakan RAK in time. Percobaan ini terdiri dari 2 Faktor yaitu (1) menggunakan bahan pemantap tanah jenis lateks dan (2) menggunakan bahan pemantap tanah jenis PAM. Masing-masing faktor terdiri dari 4 taraf yaitu Biji rumput rhodes, signal, bermuda dan cover crop PJ. Sebagai pembanding dari teknologi hydroseeding pada uji coba dilakukan penanaman secara konvensional menggunakan rumput vetiver. Sehingga jumlah total perlakuan sebanyak 9 perlakuan, yaitu :

1. PAM $3 \mathrm{gram} / \mathrm{m}^{2}+$ biji rumput bermuda $22 \mathrm{gram} / \mathrm{m}^{2}$

2. Lateks $0,51 / \mathrm{m}^{2}+$ biji rumput bermuda $22 \mathrm{gram} / \mathrm{m}^{2}$

3. PAM $3 \mathrm{gram} / \mathrm{m}^{2}+$ cover crop PJ $50 \mathrm{gram} / \mathrm{m}^{2}$

4. Lateks $0,51 / \mathrm{m}^{2}+$ cover crop $\mathrm{PJ}$ $50 \mathrm{gram} / \mathrm{m}^{2}$

5. PAM $3 \mathrm{gram} / \mathrm{m}^{2}+$ biji rumput rhodes $22 \mathrm{gram} / \mathrm{m}^{2}$

6. Lateks $0,51 / \mathrm{m}^{2}+$ biji rumput rhodes $22 \mathrm{gram} / \mathrm{m}^{2}$

7. PAM $3 \mathrm{gram} / \mathrm{m}^{2}+$ biji rumput signal $22 \mathrm{gram} / \mathrm{m}^{2}$ 
8. Lateks $0,51 / \mathrm{m}^{2}+$ biji rumput signal $22 \mathrm{gram} / \mathrm{m}^{2}$

9. Rumput vetiver Masing-masing perlakuan ditambah pupuk kandang 500 gram $/ \mathrm{m}^{2}$ dan mulsa serutan kayu $300 \mathrm{gram} / \mathrm{m}^{2}$ dan diaduk secara manual Selama 30 menit dengan menggunakan batang pengaduk. Campuran tersebut selanjutnya disemprotkan ke petak uji coba $(3 \mathrm{~m} \times 6 \mathrm{~m})$. Setiap perlakuan diulang sebanyak 3 kali ulangan dengan parameter pertumbuhan yang diukur adalah tinggi/panjang daun dan penutupan masing-masing vegetasi. Pengamatan dilakukan selama 6 bulan setelah tanam.

\section{Rancangan Analisis dan Evaluasi}

Analisis yang digunakan adalah analisis deskriptif dan analisis ragam. Analisis ini bertujuan untuk mengetahui seberapa besar pengaruh bahan pemantap tanah (PAM dan Lateks) terhadap pertumbuhan vegetasi yang ada. Analisis secara deskriptif untuk mengetahui pertumbuhan tinggi tanaman dan perkembangan penutupan tanah secara deskriptif. Analisis deskriptif yang dilakukan adalah membuat plot tinggi tanaman dan penutupan tanah terhadap waktu. Pengujian asumsi sebelum melakukan analisis ragam menggunakan RAK in time. Pengujian asumsi dilakukan secara eksploratif. Analisis ragam dengan menggunakan model RAK in time baik untuk tinggi tanaman maupun penutupan. Alpha pengujian yang digunakan adalah 5\% atau 0.05. Jika diperoleh hasil yang signifikan atau tolak H0 bagi perlakuan (petak utama) dan interaksi antara perlakuan dengan waktu, akan dilakukan uji lanjut menggunakan uji perbandingan berganda Duncan untuk perlakuan berdasarkan masing-masing waktunya. Sedangkan jika diperoleh hasil signifikan atau tolak $\mathrm{H} 0$ bagi perlakuan (petak utama) tetapi tidak untuk interaksinya dengan waktu, uji lanjut menggunakan uji perbandingan berganda Duncan akan dilakukan untuk perlakuan tanpa memperhatikan pengaruh waktunya.

Tahap selanjutnya adalah uji kontras, bilamana hasil uji Duncannya diperoleh hasil yang signifikan untuk setiap perlakuan. Uji kontras bagi perlakuan (kombinasi biji dan bahan pemantap) bertujuan mengetahui ada tidaknya berbedaan antara penanaman menggunakan pemantap lateks dan PAM. Perlakuan yang terbaik atau yang paling efektif dan efisien adalah kombinasi biji dan pengikat yang memiliki pertumbuhan tinggi tanaman dan penutupan yang paling tinggi.

Software yang digunakan untuk analisis ini adalah minitab 16, IBM SPSS Statistics 21, SAS 9.1, dan Microsoft Excel 2007.

\section{E. HASIL DAN PEMBAHASAN}

\section{Pertumbuhan Tinggi Vegetasi}

Pertumbuhan tinggi vegetasi yang diamati di lereng jalan Lingkar Gentong dan Lingkar Nagreg dilakukan selama 6 bulan, yaitu mulai awal bulan Januari sampai dengan bulan Juni 2015. Jenis vegetasi yang diamati adalah rumput vertiver, signal, rhodes, bermuda dan cover crops PJ.

Berdasarkan plot pertumbuhan tinggi vegetasi di kedua lokasi uji coba (Lingkar Gentong dan Lingkar Nagreg), terlihat rumput vetiver memiliki pertumbuhan tinggi tanaman yang lebih tinggi dibandingkan perlakuan lainnya. Terdapat perbedaan yang cukup signifikan antara rumput vetiver dengan rumput yang ditanam menggunakan teknologi hydroseeding. Rumput rhodes baik yang menggunakan pengikat PAM maupun Lateks memiliki pertumbuhan tinggi 
tanaman yang paling tinggi sejak awal pengamatan dibandingkan dengan rumput lainnya yang ditanam menggunakan teknologi ini. Vegetasi PJ dan signal baik menggunakan PAM ataupun Lateks memiliki pertumbuhan di bawah rumput rhodes. Sedangkan rumput bermuda baik menggunakan PAM maupun Lateks memiliki pertumbuhan tinggi tanaman yang paling rendah di antara yang lainnya. Pengaruh penggunaan pengikat PAM dan Lateks pun tidak terlihat signifikan, karena untuk setiap rumput pertumbuhannya hampir sama secara deskriptif. Selain itu, terjadi penurunan tinggi tanaman pada rumput bermuda dari waktu ke-4 menuju ke-5. Hal ini dapat disebabkan oleh beberapa faktor yang tidak dapat dikontrol selama percobaan berlangsung.

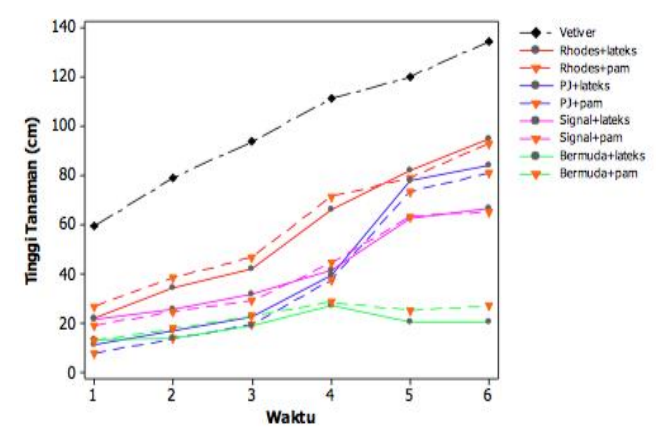

Berdasarkan analisis ragam dengan menggunakan model RAK in time terlihat bahwa pada taraf nyata $5 \%$, interaksi antara kombinasi biji dan bahan pemantap tanah juga memiliki $p$-value < alpha, sehingga $\mathrm{H} 0$ ditolak menunjukkan bahwa terdapat interaksi antara kombinasi biji dan bahan pemantap dengan waktu yang mempengaruhi tinggi tanaman. Perlakuan (kombinasi biji dan bahan pemantap tanah) sebagai petak utama memiliki $p$-value sebesar 0.000 dengan alpha sebesar 5\% diperoleh p-value < alpha, sehingga tolak H0. Artinya, minimal ada satu kombinasi biji dan bahan pemantap yang dipengaruhi oleh interaksinya dengan waktu memiliki pengaruh berbeda terhadap tinggi tanaman. Begitu pula dengan waktu sebagai petak utama yang memiliki $p$ value < alpha atau memperoleh kesimpulan tolak H0. Artinya, waktu yang dipengaruhi oleh interaksinya dengan perlakuan memiliki pengaruh terhadap tinggi tanaman. Sedangkan kelompok memiliki p-value > alpha $(0.189>0.05)$, sehingga diperoleh tak tolak H0. Artinya, kelompok tidak mempengaruhi tinggi tanaman.

Untuk mengetahui perbedaan pengaruh yang dihasilkan oleh kombinasi biji dan pengikat dilakukan uji lanjut menggunakan uji Duncan (lihat Tabel 3 dan Tabel 4). Hasil pengujian Duncan menunjukkan bahwa kombinasi biji dan bahan pemantap tanah dengan huruf yang sama pada satu kolom (pada satu waktu) menandakan bahwa kombinasi biji dan pengikat tersebut tidak memiliki perbedaan pengaruh terhadap tinggi tanaman pada taraf nyata 5\%. Seiring dengan bertambahnya waktu, terlihat bahwa masing-masing perlakuan semakin memberikan pengaruh yang berbeda terhadap tinggi tanaman ditandai dengan semakin banyaknya kelompok yang terbentuk. Dari uji ini dapat terlihat bahwa rumput vetiver sebagai rumput yang tidak ditanam menggunakan teknologi hydroseeding memiliki pertumbuhan tinggi tanaman yang paling baik di setiap waktu. Hal ini disebabkan karena rumput vetiver tidak ditanam dari biji melainkan ditanam secara stek

\section{Tabel 3}

Hasil uji Duncan untuk kombinasi biji dan pengikat berdasarkan waktunya untuk tinggi tanaman di Lereng Jalan Lingkar Gentong 


\begin{tabular}{|c|c|c|c|c|c|c|}
\hline \multirow{2}{*}{ Perlakuan } & \multicolumn{6}{|c|}{ Waktu } \\
\hline & 1 & 2 & 3 & 4 & 5 & 6 \\
\hline \multirow{2}{*}{ Bermuda+lateks } & 13.50 & 14.00 & 19.17 & 27.00 & 20.33 & 20.33 \\
\hline & $a b$ & a & a & a & a & a \\
\hline \multirow{2}{*}{ Bermuda+pam } & 12.93 & 17.80 & 22.87 & 28.67 & 25.33 & 27.00 \\
\hline & $a b$ & a & a & $a b$ & a & a \\
\hline \multirow{2}{*}{ PJ+lateks } & 11.30 & 17.00 & 22.80 & 39.67 & 78.00 & 84.00 \\
\hline & $a b$ & a & a & $\mathrm{bc}$ & c & cd \\
\hline \multirow{2}{*}{ PJ+pam } & 7.90 & 13.67 & 19.57 & 37.50 & 73.33 & 81.00 \\
\hline & a & a & a & $\mathrm{abc}$ & b c & cd \\
\hline \multirow{2}{*}{ Signal+lateks } & 21.80 & 25.80 & 31.63 & 41.80 & 62.33 & 66.50 \\
\hline & b & $a b$ & a & c & b & b \\
\hline \multirow{2}{*}{ Signal+pam } & 19.23 & 24.67 & 29.23 & 44.40 & 63.33 & 65.33 \\
\hline & a b & $a b$ & a & c & b & b \\
\hline \multirow{2}{*}{ Rhodes+lateks } & 22.03 & 34.20 & 42.17 & 66.17 & 82.00 & 94.67 \\
\hline & $\mathrm{b}$ & b & b & d & c & d \\
\hline \multirow{2}{*}{ Rhodes+pam } & 22.03 & 34.20 & 42.17 & 71.33 & 79.00 & 93.00 \\
\hline & b & b & b & d & c & d \\
\hline \multirow{2}{*}{ Vetiver } & 59.50 & 79.00 & 93.83 & 111.03 & 120.00 & 134.33 \\
\hline & c & c & c & e & d & e \\
\hline
\end{tabular}

\section{Tabel 4}

Hasil uji Duncan untuk kombinasi biji dan pengikat berdasarkan waktunya untuk tinggi tanaman di Lereng Jalan

\begin{tabular}{|c|c|c|c|c|c|c|}
\hline \multirow{2}{*}{ Perlakuan } & \multicolumn{6}{|c|}{ Waktu } \\
\hline & 1 & 2 & 3 & 4 & 5 & 6 \\
\hline \multirow{2}{*}{ Bermuda+lateks } & 11.93 & 14.10 & 19.10 & 26.20 & 27.37 & 26.28 \\
\hline & a & a & $a b$ & a & a & a \\
\hline \multirow{2}{*}{ Bermuda+pam } & 10.53 & 17.47 & 21.83 & 27.07 & 26.10 & 25.57 \\
\hline & a & $a b$ & $a b c$ & a & a & a \\
\hline \multirow{2}{*}{ PJ+lateks } & 11.10 & 14.93 & 24.00 & 34.43 & 60.43 & 73.47 \\
\hline & a & a & $b c$ & $b$ & $b$ & $c d$ \\
\hline \multirow{2}{*}{ PJtpam } & 6.13 & 11.70 & 15.67 & 34.93 & 71.18 & 75.59 \\
\hline & a & a & a & $b$ & c & $c d$ \\
\hline \multirow{2}{*}{ Signal+pam } & 15.37 & 23.10 & 27.70 & 43.43 & 56.39 & 65.20 \\
\hline & $b$ & $b c$ & c & $c$ & $b$ & $b$ \\
\hline \multirow{2}{*}{ Signal+lateks } & 22.10 & 28.73 & 35.93 & 48.80 & 67.80 & 90.23 \\
\hline & c & $c d$ & $d$ & c & c & e \\
\hline \multirow{2}{*}{ Rhodes+pam } & 20.50 & 30.13 & 37.97 & 48.30 & 59.83 & 78.63 \\
\hline & $b$ & $d$ & $d$ & c & $b$ & $c d$ \\
\hline \multirow{2}{*}{ Rhodes+lateks } & 32.83 & 40.43 & 53.40 & 64.60 & 72.83 & 81.70 \\
\hline & $d$ & e & e & $d$ & c & $d$ \\
\hline \multirow{2}{*}{ Vetiver } & 59.60 & 75.00 & 87.93 & 114.30 & 131.30 & 148.93 \\
\hline & e & $t$ & $f$ & e & $d$ & $f$ \\
\hline
\end{tabular}

Untuk perlakuan yang ditanam menggunakan teknologi hydroseeding, pada bulan ke-1, kombinasi PJ dan PAM hanya memiliki pengaruh yang berbeda dengan kombinasi antara Signal dan Lateks, serta dengan kombinasi antara Rhodes baik dengan PAM maupun Lateks. Sedangkan mulai bulan ke-2, perbedaan pengaruh antar kombinasi biji dan bahan pemantap tanah semakin mencolok. Kombinasi antara Rhodes baik dengan PAM maupun Lateks memiliki pertumbuhan tinggi tanaman yang paling baik dari hasil penanaman menggunakan teknologi hydroseeding, terutama dari bulan ke-3 hingga ke-6. Sebaliknya, kombinasi antara Bermuda baik dengan Lateks maupun PAM menjadi kombinasi yang memberikan pengaruh paling rendah terhadap tinggi tanaman, terutama pada bulan ke-5 dan ke-6.

Selain pengujian yang telah dilakukan di atas, juga ingin diketahui perbedaan pengaruh antara masingmasing biji dengan rumput Vetiver dan perbedaan antar bahan pemantap. Untuk itu, dilakukan pengujian kontras untuk mengetahui perbedaan pengaruhnya.

\section{Tabel 5}

Hasil pengujian kontras untuk tinggi tanaman

\begin{tabular}{|c|c|c|c|c|c|}
\hline Sumber Keragaman & $\mathrm{db}$ & $\begin{array}{l}\text { Jumlah } \\
\text { Kuadrat }\end{array}$ & $\begin{array}{l}\text { Kuadrat } \\
\text { Tengah }\end{array}$ & $\mathrm{F}$ & p-value \\
\hline Vetiver vs Lainnya & 1 & 57117.017 & 57117.017 & 220.378 & 0.000 \\
\hline $\begin{array}{l}\text { Bermuda vs Rhodes, } \\
\text { Signal, PJ }\end{array}$ & 1 & 17555.475 & 17555.475 & 67.735 & 0.000 \\
\hline Rhodes vs Signal, PJ & 1 & 6148.267 & 6148.267 & 23.722 & 0.000 \\
\hline Signal vs PJ & 1 & 13.347 & 13.347 & 0.051 & 0.823 \\
\hline Lateks vs Pam & 1 & 0.456 & 0.456 & 0.002 & 0.967 \\
\hline Galat(a) & 16 & 4146.842 & 259.178 & & \\
\hline
\end{tabular}

Berdasarkan hasil pengujian kontras pada taraf nyata 5\% diperoleh bahwa terdapat perbedaan yang signifikan antara pertumbuhan rumput Vetiver dengan pertumbuhan tanaman yang ditanam menggunakan teknologi hydroseeding. Biji Bermuda pun berbeda dengan ketiga jenis biji lainnya dari segi pertumbuhan tanamannya. Rhodes juga memiliki perbedaan pertumbuhan tinggi tanaman dengan biji PJ dan Signal. Sedangkan biji PJ dan Signal tidak memiliki perbedaan satu sama lain dalam segi pertumbuhan tinggi tanamannya. Penggunaan pengikat Lateks dan PAM juga tidak memiliki pengaruh yang signifikan terhadap pertumbuhan tinggi 
tanamannya. Dapat dikatakan bahwa pengaruh Lateks sama dengan PAM ditandai dengan nilai $\mathrm{p}$ yang hampir 1 . Sehingga, untuk teknologi hydroseeding ini Lateks cukup baik untuk menggantikan PAM sebagai bahan pengikat yang digunakan.

Rancangan ini memiliki nilai koefisien determinasi yang sangat besar yaitu sebesar 92,30\%. Keragaman tinggi tanaman yang telah dijelaskan oleh kombinasi biji dan pengikat, waktu beserta interaksinya serta kelompok adalah sebesar $92,30 \%$, sedangkan $7,70 \%$ lainnya dijelaskan oleh faktor-faktor lain yang mempengaruhi tinggi tanaman tetapi tidak dimasukkan ke dalam model ini. Besarnya nilai koefisien determinasi menunjukkan bahwa model ini telah merepresentasikan hampir semua informasi yang ada pada data hasil percobaan ini.

\section{Penutupan Vegetasi di Lereng}

Seperti halnya tinggi vegetasi, pertumbuhan penutupan vegetasi yang diamati di lereng jalan Lingkar Gentong dan Lingkar Nagreg juga dilakukan selama 6 bulan, yaitu mulai awal bulan Januari sampai dengan bulan Juni 2015. Jenis vegetasi yang diamati adalah rumput Vertiver, Signal, Rhodes, Bermuda dan Cover Crops (PJ). Berdasarkan plot penutupan vegetasi (lihat Gambar 4) terlihat bahwa pada awal pengamatan terdapat tiga kelompok penutupan tanah oleh vegetasi, yaitu:

Kelompok Pertama terdiri dari perlakuan dengan rumput Vetiver, PJ dan lateks, serta PJ dan PAM yang memiliki persen penutupan paling rendah dibanding perlakuan lainnya di awal pengamatan. Namun, mulai dari waktu pengamatan yang ke-4 ketiga perlakuan ini memiliki kenaikan persen penutupan yang sangat signifikan, sehingga di pengamatan yang ke-6 ketiga perlakuan ini memiliki penutupan $100 \%$, kecuali vetiver hanya $96,67 \%$.

Kelompok Kedua terdiri dari perlakuan dengan rumput Bermuda dan PAM, serta Rhodes dan Lateks yang memiliki penutupan sekitar $50 \%$ di awal pengamatan. Berbeda dengan kelompok satu yang cenderung memiliki kesamaan dalam hal kenaikan penutupannya, untuk kelompok ini kenaikan penutupannya berbeda. Untuk perlakuan dengan menggunakan rumput Bermuda dan PAM, penutupannya justru menjadi yang paling rendah hingga akhir pengamatan, atau dengan kata lain penutupan tanah menggunakan perlakuan ini cenderung lambat. Sedangkan untuk perlakuan yang menggunakan rumput Rhodes dan Lateks, penutupannya memiliki kenaikan yang cukup tinggi sehingga di akhir pengamatan memiliki penutupan sebesar $100 \%$.

Kelompok Ketiga terdiri dari perlakuan dengan rumput Signal baik untuk Lateks maupun PAM, Rhodes dan PAM serta Bermuda dan Lateks yang memiliki penutupan cukup tinggi sekitar $65 \%$ di awal pengamatan. Namun, untuk perlakuan dengan menggunakan rumput Bermuda dan Lateks, kenaikan penutupannya sangat lambat. Sehingga, di akhir pengamatan persen penutupannya menjadi kedua yang paling rendah. Perlakuan dengan menggunakan rumput Rhodes dan PAM memiliki kenaikan penutupan yang konsisten hingga di akhir pengamatan penutupannya sebesar $\quad 97.67 \%$. Sedangkan untuk perlakuan menggunakan rumput Signal baik menggunakan PAM maupun Lateks, kenaikan proses penutupan tanahnya cenderung konsisten, sehingga di 
akhir pengamatan penutupannya mencapai $100 \%$.

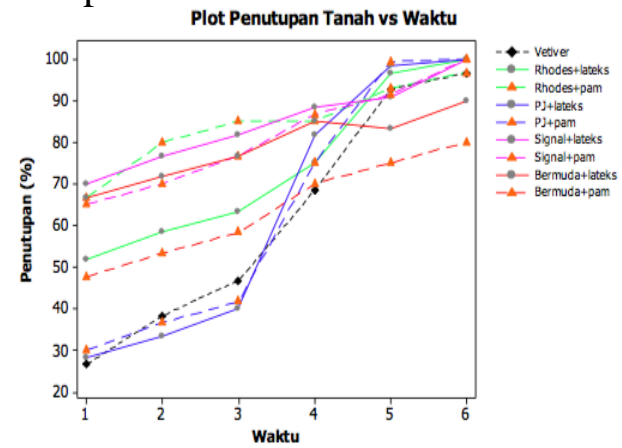

Gambar 4. Plot Penutupan vs Waktu

\section{F. KESIMPULAN DAN SARAN}

\section{KESIMPULAN}

Hasil Penelitian yang telah dilakukan menunjukkan:

1. Adanya interaksi antara kombinasi biji dan bahan pemantap tanah dengan waktu yang mempengaruhi pertumbuhan (tinggi dan penutupan) tanaman. Jenis vegetasi yang menunjukkan pertumbuhan yang baik adalah rumput signal, rumput rhodes dan cover crops PJ.

2. Penggunaan bahan pemantap tanah jenis lateks dan PAM dalam campuran hydroseeding tidak memiliki pengaruh yang signifikan terhadap pertumbuhan. Oleh karena itu, lateks dapat dapat digunakan sebagai pengganti PAM dalam campuran hydroseeding

\section{SARAN}

Dalam penelitian ini masih ada kendala yang ditemukan selama proses penelitian berjalan yaitu faktor lingkungan dan waktu pengeringan lateks. Oleh karena itu peneliti menyarankan:

1. Faktor lingkungan yang tidak dapat terkontrol yaitu curah hujan, sehingga untuk menghasilkan data penelitian yang akurat sebaiknya dilakukan penelitian lanjutan dengan menggunakan alat simulator curah hujan.

2. Lateks membutuhkan waktu untuk melekat pada saat di semprotkan pada permukaan lereng sehingga perlu dilakukan penelitian lanjutan kombinasi lateks dengan PAM.

Dalam upaya memanfaatkan bahan lokal dan meningkatkan pendapatan petani karet, pemanfaatan lateks dapat dijadikan sebagai alternatif pengganti PAM dalam campuran hydroseeding.

\section{DAFTAR PUSTAKA}

Abdurachman, A. dan S. Sutono. 2005. Teknologi pengendalian erosi lahan berlereng. Dalam Teknologi Pengelolaan Lahan Kering: Menuju pertanian produktif dan ramah lingkungan. Pusat Penelitian dan Pengembangan Tanah dan Agroklimat, Bogor

Arsyad, S. 2010. Konservasi Tanah dan Air. IPB Press. Bogor

D. Feldman, A. J. Hartomo, Bahan Polimer Konstruksi Bangunan, Gramedia Pustaka Utama.Jakarta

Dumanauw, J.F. 1982. Mengenal Kayu. PT. Gramedia. Jakarta

Gohl, B. 1981. Tropical Feeds. Food and Agriculture Organization of The United Nations. Roma

K. Moto.V.Julian, Syamsudin, T.A. Wiradi dan S.R. Wijaya. 2004. Pembuatan Plolimer Lateks Emulsi untuk Peningkatan CBR Tanah Sub-Grade pada Konstruksi Jalan: Jurnal Makara Teknologi Vol 8, no 2 (2004).

Mashayekhan dan Hojjati, 2013. Effect of wood chip application on root growth of oak seedling and weed 
control in northern Iran Journal of Forestry Research (2013) 24: 607.

Masduqi, A.F. M.Izzati dan E. Saptiningsih. 2012. Pengaruh Penambahan Pembenah Tanah Dari Stratiotes L. Dan Ceratophyllum demersum L., Pada Tanah Pasir dan LIat Terhadap kapasitas Lapang dan Pertumbuhan Kacang Hijau (Vigna radiate L.,):Jurnal Anatomi Fisiologi Vol 12, No 1 (2012). Melalui http://ejournal.undip.ac.id> (diakses 15 September 2017)

Marschner H. 1995. Mineral nutrition of higher plant. Second Edition.Academic Press. Harcourt Brace\& Company, Publisher. London

Morris, M. 2007. Asia_s public and private maize seed industries changing. Asian Seed.2 : 3-4.

Nanny Kusminingrum dan Asep Sunandar. 2014. Komposisi Campuran BijiRumput Untuk Bahan Pengendali Erosi Permukaan Dengan Teknologi Hidrosiding. Prosiding Kolokium Jalan dan Jembatan ke-7. ISBN :978-602-264-038-7

Novizan. 2002. Petunjuk Pemupukan yang Efektif. PT. AgroMedia Pustaka. Depok.

Oyo,T, Hidayat., I.Heliati dan I.Solihat. 1997. Teknik Budidaya Rumput Brachiaria Decumbens. Lokakarya Fungsional Non Peneliti: Balai penelitian Ternak, Ciawi. Bogor. Melalui http://balitnak.Balitbang.pertania n.go.id(diakses 15 agustus 2017)

Reksohadiprodjo, S. 1985. Produksi Tanaman Hijauan Makanan Ternak Tropika. BPFE,
Yogyakarta.

Riyanto, H.D.,U.W.H.Pahlana dan S.Abdiyani.2010.Teknik

Rehabilitasi Lahan Dengan sistem Hydroseeding. Program Insentif Riset Terapan: Balai penelitian Kehutanan Solo, Melalui $\quad$ http://bpksolo.litbang.dephut.go.id(diakses 25 juli 2017)

Shelton. M, 2007. Brachiaria decumbens. Melalui http://www.fao.org.ac.isd> Diakses 12 september 2017)

Sunandar A, 2013). Penanganan ERosi Permukaan Lereng Jalan Secara Vegetatif Melalui Teknologi Hydroseeding. Pusat Litbang Jalan dan Jembatan.Bandung.

Sumarsono. 2007. Buku Ajar Ilmu Tanaman Makanan Ternak. Fakultas Peternakan. Universitas Dipenogoro. Semarang. Melalui http://eprints.undip.ac.isd $>$ (Diak ses 20 Agustus 2017)

Sutrisno, Anton. 2011. Rumput bermuda (Cynodon dactylon), Bertahan dan Menyebar Dengan Luar Biasa. Melalui http://antonsutrisno.webs.com. (Diakses pada tanggal 2 January 2016)

Styczen, M.E dan R.P.C Morgan. 1995. Engineering Properties of Vegetation. Di dalam: Slope Stabilization and erosion Control: A Bioengineering Approach. Edisi Morgan R.P.C dan R.J. Rickson. E and FN SPON. An Imprint of Chapman \& Hall, London. Hlm: 5-58.

Turgeon, A. J., 2002. Turfgrass Management. Sixth Edition. Prentice Hall. New Jersey.

Undang-Undang Republik Indonesia Nomor 12 Tahun 1992. Sistem Budidaya Tanaman. Jakarta 
Yulianda. 2009. Pertumbuhan dan Hasil

Tanaman Caisin (Brassica juncea L) Berdasarkan Variasi Mulsa dan Jarak Tanam. Online kim. urg. ac. Id/index. php.KIMFIIP/article/download/2 445/2424. (Diakses 22

Sepetember 2017)

.http://archive.agric.wa.gov.au/objtwr/i mported assets/content/past/rhod esogr ass.pdf .(Diakses 15 september 2017) 